\title{
Guide imagery and music (GIM) untuk menurunkan kecemasan kompetitif pada atlet sebelum bertanding
}

Muhammad Febrian Al Amin ${ }^{\text {** }}$, Iswinarti ${ }^{2}$

Fakultas Psikologi, Universitas Muhammadiyah Malang, Indonesia

\begin{tabular}{l}
\hline Info Artikel \\
\hline Sejarah Artikel: \\
Diterima \\
06 Januari 2019 \\
Direview \\
23 Januari 2020 \\
Disetujui \\
24 Februari 2020 \\
Dipublikasikan \\
27 Februari 2020 \\
\hline Keywords: \\
Athletes, \\
Competitive anxiety, \\
Guided imagery and music \\
theraphy (GIM).
\end{tabular}

Abstrak

Objektif: Kecemasan di dalam olahraga merupakan salah satu faktor yang mempengaruhi performa atlet pada saat menghadapi pertandingan. Kecemasan yang muncul tidak hanya terdiri dari komponen kognitif, tapi juga melibatkan komponen fisiologis atau somatik. Penelitian ini bertujuan untuk menguji efek intervensi guide imagery dan music (GIM) dalam mengatasi kecemasan kompetitif atlet sebelum bertanding.

Metode: Subjek terdiri atas tiga kelompok eksperimen dan satu kelompok kontrol atlet futsal. Kuesioner yang digunakan adalah skala Kecemasan kompetitif yang disusun sendiri oleh peneliti untuk pengumpulan data. Desain penelitian yang digunakan kuasi eksperimen dengan bentuk non-randomized pretest-posttest control group design. Analisis data menggunakan analisis non parametric yaitu Uji Wilcoxon, Kruskal-Wallis dan Mann Whitney.

Temuan: Hasil penelitian menunjukkan intervensi Guide Imagery and music efektif dalam menurunkan kecemasan kompetitif atlet. Hasil ini terlihat dari penurunan skor kecemasan kompetitif pada kelompok eksperimen saat pre-test dan post-test. Selain itu, adanya perbedaan signifikan kecemasan kompetitif saat dilakukan uji beda dengan Uji Mann Whitnney antara kelompok eksperimen dan kelompok kontrol.

Kesimpulan: terapi Guide Imagery and music dapat digunakan untuk menurunkan kecemasan kompetitif pada atlet sebelum pertandingan.

\section{Guide imagery and music (GIM) to reduce competitive anxiety in} athletes before competing

Objectives: Anxiety in sports is one of the factors that affect athlete performance when facing a match. Anxiety that arises not only consists of cognitive components, but also involves physiological or somatic components. This study aims to examine the effect of guide imagery and music (GIM) interventions in overcoming competitive anxiety in athletes before competing.

Method: The subjects consisted of three experimental groups and one control group of futsal athletes. The questionnaire used was a competitive Anxiety scale that was compiled by the researcher himself for data collection. The research design used was quasiexperimental with non-randomized pretest-posttest control group design. Data analysis used non-parametric analysis, namely the Wilcoxon, Kruskal-Wallis and Mann Whitney Tests.

Findings: The results showed the Guide Imagery and music intervention was effective in reducing athletes' competitive anxiety. This result can be seen from the decrease in competitive anxiety scores in the experimental group during the pre-test and post-test. In addition, there was a significant difference in competitive anxiety when a different test was performed with the Mann Whitnney Test between the experimental group and the control group.

Conclusions: Guide Imagery and music therapy can be used to reduce competitive anxiety in athletes before a match.

\footnotetext{
*Alamat korespondensi:

Kampus 3 UMM JI. Raya Tlogomas No.246 Malang Jawa Timur 65 I44

muhammadfebrian95@gmail.com
} 


\section{Pendahuluan}

Kecemasan adalah kondisi yang umum dihadapi oleh siapa saja saat akan menghadapi sesuatu yang penting, termasuk juga para atlet. Rasa cemas muncul karena ada bayangan-bayangan yang salah berkaitan dengan pertandingan yang akan dihadapi. Dalam dunia olahraga, banyak fenomena di mana seorang atlet dalam olahraga mempunyai performa yang tidak stabil, hal ini dipengaruhi oleh faktor situasi dan individu (Ramzaninezhad, Keshtan, Shahamat, \& Kordshooli, 2009).

Salah satu metode yang cukup sering digunakan untuk mengurangi kecemasan oleh berbagai kalangan yakni relaksasi dan musik. Teknik relaksasi merupakan suatu bentuk penanganan dengan cara mengajak serta mengantar klien untuk bersantai dan berimajinasi, dengan asumsi bahwa dengan bersantai otot-otot dapat membantu mengurangi tegangan psikologis (Chaplin, 2002). Teknik yang menggunakan dasar relaksasi sering digunakan dalam olahraga karena memiliki efek pada performa dan pembelajaran, seperti salah satu contoh nya teknik imagery. Imagery merupakan teknik intervensi kognitif, di mana individu menggunakan seluruh indra yang ia miliki untuk menciptakan atau menciptakan kembali pengalaman dalam pikirannya (Vealey \& Greenleaf, 200I). Melalui teknik imagery, atlet dapat menciptakan kembali gambaran mengenai pengalamannya di masa lampau seperti mengingat kembali pertandingan yang baru saja ia menangkan. Selain itu atlet juga dapat menciptakan pengalaman baru yang belum pernah ia alami dengan cara mengambil bagian dari gambaran yang tersimpan dalam memori dan menyusunnya kembali menjadi sebuah pengalaman baru.

Di Indonesia, penelitian mengenai imagery sudah dilakukan antara lain untuk meningkatkan keterampilan senam serta kepercayaan diri pada atlet usia 10-12 tahun (Firmansyah, 20II), dan peningkatan pencapaian pembelajaran kemampuan motorik pada atlet badminton usia 10-12 tahun (Hidayat, 20II). Musik secara psikologis bisa menentukan aktivitas mood termasuk persepsi dan kognisi. Musikal merupakan salah satu aspek penting bagi manusia, dalam berbagai penelitian ilmiah, dikatakan bahwa musik bisa berdampak pada psikologis seseorang seperti mempengaruhi suasana hati, emosi, mempengaruhi (perasaan senang/ ketidak senangan), kognitif (proses berpikir) perilaku, sehingga menurut Djohan (2005) Penggunaan musik sangat di anjurkan sebagai peralatan terapis untuk memperbaiki, memelihara, mengembangkan mental, fisik, dan kesehatan emosi. Musik diyakini dapat digunakan untuk relaksasi, meringankan stres, dan mengurangi kecemasan karena musik merupakan sebuah rangsangan pendengaran yang terorgaisasi, yang terdiri atas melodi, ritme, harmoni, bentuk, dan gaya music sehingga dengan mendengarkan musik yang mampu memperbaiki konsentrasi, ingatan dan persepsi sosial (Aizid, 200I).

Musik merupakan kesatuan dari suara, melodi, ritme yang bisa membangkitkan emosi.Terapi music dapat membantu orang-orang yang memiliki masalah emosional, dengan musik seseorang bias merasa rileks, ikut bahagia, maupun sedih. Terapi musik juga bias menangani seseorang ketika dalam keadaan stress dan cemas (Aizid, 20I I).

Pendekatan atas kecemasan kompetitif atlet sebelumnya banyak yang menggunakan teknik imageri saja, jarang ada unsur musik di dalam nya, padahal dari hasil penelitian sebelumnya musik merupakan sarana penting untuk mensugesti dan meninduksi intevervensi imagery yang akan dilakukan, sehingga pendekatan atau intervensi yang digunakan dalam penelitian ini adalah pendekatan guide imagery and music (GIM). Melalui teknik ini, atlet yang dihadapkan pada situasisituasi yang menimbulkan kecemasan dengan cara membuat gambaran situasi kecemasan dalam pikirannya, lalu atlet diminta untuk membayangkan tindakan yang dapat ia lakukan untuk mengatasinya dengan diiringin musik. Hal ini penting karena perilaku dan performa atlet berhubungan dengan pikiran dan perasaan mereka ketika bertanding (Vealey \& Greenleaf, 200I).

Kecemasan atau dalam Bahasa Inggris "anxiety" berasal dari Bahasa Latin "angustus" yang berarti kaku, dan "ango, anci" yang berarti mencekik. Kecemasan adalah emosi yang tidak menyenangkan, seperti perasaan tidak enak, perasaan kacau, was-was dan ditandai dengan istilah kekhawatiran, keprihatinan, dan rasa takut yang kadang dialami dalam tingkat dan situasi yang berbeda-beda 
(Atkinson, Atkinson R, \& Hilgard 1994). Kecemasan memiliki komponen trait yang disebut sebagai trait anxiety dan komponen state yang disebut sebagai state anxiety (Davies, 1989). Trait anxiety merupakan disposisi laten yang dimiliki seseorang untuk menunjukkan reaksi cemas atau tidak. Individu yang memiliki trait anxiety secara umum akan merasa cemas di berbagai situasi, State anxiety merupakan perasaan subjektif dari kecemasan yang dialami individu pada situasi tertentu yang dirasakan sebagai ancaman, meskipun bahaya sebenarnya tidak ada. State anxiety cenderung berubah dari waktu kewaktu, dan sangat dipengaruhi oleh situasi dan kondisi yang terjadi saat ini (Satiadarma, 2000).

Kecemasan kompetitif merupakan hasil dari kecemasan dasar atlet dalam mempersepsikan situasi kompetisi (Spielberger, 1966). Menurut Jarvis (1999), kecemasan yang kita rasakan pada satu saat tertentu merupakan hasil pembentukan psikologis individu dan karakteristik dari situasi dimana individu berada. Oleh sebab itu, faktor individual dan situasional perlu diperhitungkan ketika menghadapi suatu pertandingan. Hasil peneltian membuktikan bahwa kecemasan berpengaruh besar terhadap kemungkinan penampilan atlet, yang dengan sendirinya akan berpengaruh terhadap prestasinya (Setyobroto, 2002).

Martens (1990) mengembangkan teori kecemasan kompetitif multidimensi, yang menjelaskan bahwa kecemasan kompetitif termanifestasikan dalam tiga bentuk, yaitu kecemasan kognitif, kecemasan somatik, dan kepercayaan diri. Lebih lanjut, Martens (1990) menjelaskan bahwa kecemasan kognitif adalah harapan negatif dan kekhawatiran kognitif tentang diri sendiri, situasi yang dihadapi, dan potensi konsekuensi yang akan dihadapi. Misalnya, keraguan tentang diri dan kekhawatiran tentang kekalahan. Kecemasan somatik adalah persepsi dari gairah fisiologis seseorang, misalnya, peningkatan denyut jantung, gemetar, dan berkeringat. Sedangkan, kepercayaan diri adalah keyakinan seseorang dalam menghadapi tantangan tugas yang akan dilakukan, misalnya berbentuk perasaan santai dan aman.

Raley (2006) menyebutkan bahwa guide imagery and music adalah metode psikoterapi dengan mendengarkan music klasik dengan keadaan santai untuk meningkatkan imajinasi dan aktualisasi diri. Guide imagery and music adalah kombinasi dari intervensi kognitif imagery dan terapi music, guide imagery and music memfokuskan imajinasi klien dengan fasilitas music. Efek music digunakann untuk memperkuat relaksasi individu sehingga imajinasi maupun sugesti bisa dengan mudah diinduksikan (Bee \& Wyatt, 2009).

Guide imagery and music merupakan gabungan antara guide imagery dan terapi musik yang memberikan efek kepada individu untuk mengintregasikan aspek emosi, mental, dan fisik (Bonny. Helen \& Savary, 1986). Penelitian menyebutkan manfaat dari guide imagery and music adalah dapat mengurangi kecemasan. (Branon, Feist \&Updegraff, 20I3). Selain itu Guided imagery juga dapat mengurangi kecemasan (Kwekkeboom, et al. 20I0).

Domenech \& Montserrat (2008) menyebutkan ada empat fase didalam Guide Imagery and Music. Fase pertama adalah prelude, pada fase ini individu mengungkapkan keluhan yang sedang dirasakan. Fase kedua adalah induction pada fase ini terapis akan memberikan sugesti verbal untuk merilekskan tubuh individu dan mempersiapkan individu untuk mendengarkan music beserta bimbingan imageri. Fase ketiga adalah Music-Imagery Experience, pada fase ini subjek akan di beri bimbingan imageri dan diperdengarkan music. Fase keempat adalah postlude, pada tahap ini adalah fase untuk mengakhiri proses guide imagery and music.

Guide imagery and music biasanya dilakukan pada ruangan yang kondusif, tetapi jika ada beberpa keadaan yang mengganggu maka hal yang bisa dilakukan dengan meningkatkan volume music (Short, 2003). Ada dua titik pandang dalam pelaksanaan GIM ini yang pertama adalah titik pandang, terapis akan membimbing individu imajinasinya dan ditujukan pada insight baru dari masalahnya, kemudian yang kedua titik pandang terapis menelaah musik dan pengalaman imajinatif yang berlangsung dalam diri klien. Banyak studi telah menunjukkan bahwa jenis musik untuk terapi 
musik tidak harus musik klasik (Djohan, 2006). Musik pop maupun musik modern dengan tanpa vokal bisa digunakan pada intervensi ini (Good, 1990). Lama pemberian pada intervensi dapat disesuaikan dengan kebutuhan, guide imagery and music dapat diberikan sekitar 15-30 menit bahkan sampai 2 jam (Short, 2003).

Berdasarkan uraian tersebut, tujuan dalam pemberian Guide imagery and music (GIM) dalam penelitian ini adalah untuk mengatasi kecemasan kompetitif atlet sebelum bertanding. Intervensi Guide Imagery and Music memberikan fokus imajinasi individu yang difasilitasi oleh musik. Musik memberikan efek penguatan pada relaksasi sehingga sugesti mudah untuk diinduksikan pada individu.

\section{Metode}

Pada penelitian ini, pendekatan yang digunakan adalah pendekatan kuantitatif dan berjenis quasi experimental design, dimana kelompok perlakuan dan kelompok kontrol tidak dippilih secara random (Sugiyono, 2015). Terdapat empat kelompok yaitu kelompok pertama (kelompok perlakuan dengan intervensi guide imagery), kelompok kedua (kelompok perlakuan dengan intervensi music therapy) kelompok ketiga (kelompok perlakuan dengan intervensi guide imagery and music) dan kelompok keempat (kelompok kontrol). Kelompok perlakuan diberi pratest untuk mengetahui keadaan awal, kelompok perlakuan diberikan perlakuan dan kelompok kontrol tidak. Setelah itu dilakukan pasca test untuk mengetahui perbedaan kelompok eksperimen satu, dua, tiga dan kelompok kontrol (Sugiyono, 20I5).

Perubahan yang terjadi diukur dengan membandingkan data yang diambil sebelum dan setelah treatment/perlakuan diberikan. Pengukuran data sebelum dan setelah treatmen dilakukan secara kuantitatif. Data kuantitatif didapat dengan melakukan pengukuran terhadap tingkat kecemasan sebelum pertandingan dengan menggunakan alat ukur skala kecemasan kompetitif yang telah disusun oleh peneliti.

\section{Tabel I}

Desain eksperimen quasi control group Pra test-Pasca test Design

\begin{tabular}{llll}
\hline Group & Pre-test & Perlakuan & Post-Test \\
\hline Eksperimen I & 01 & X & 02 \\
Eksperimen 2 & 03 & $X$ & 04 \\
Eksperimen 3 & 05 & $X$ & 06 \\
Kontrol & 07 & - & 08 \\
\hline
\end{tabular}

Peneliti menggunakan metode non probability atau non random sampling dalam penelitian ini. Metode ini digunakan ketika jumlah elemen dalam populasi tidak diketahui atau tidak dapat diidentifikasi secara individual, pengambilan sampel secara sengaja sesuai dengan kriteria yang telah ditentukan (Kumar, 1999). Kriteria subjek meliputi: (I) Atlet berkewarganegaraan indonesia yang akan atau siap bertanding, (2) Anggota Atlet dari Universitas/ Sekolah/Tim (3) bersedia mengikuti intervensi yang akan diberikan oleh peneliti.

Peneliti menetapkan jumlah partisipan yang ikut serta sebanyak satu tim Futsal untuk satu perlakuan, setelah itu peneliti menghubungi empat klub futsal kota malang dengan maksu memberikan kemudahan akses bagi peneliti untuk melakukan penelitian. Peneliti meminta ijin kepada pengurus klub untuk melakukan penelitian. Setelah itu, pengurus keempat klub tersebut meminta peneliti untuk langsung berbicara dengan pelatih. Peneliti menjelaskan kepada pelatih mengenai penelitian dan kriteria partisipan yang dibutuhkan dalam penelitian. Keempat klub tersebut mengizinkan peneliti untuk melakukan intervensi penelitian.

Variabel penelitian ini adalah kecemasan kompetitif atlet. Instrumen dalam yang digunakan untuk mengukur kecemasan kompetitif adalah skala kecemasan kompetitif yang disusun oleh peneliti 
sendiri. Skala kecemasan ini disusun terdiri dari 36 item yang dibagi menjadi 3 subskala terdiri dari: Cognitive state anxiety yang terdiri dengan 6 item favourable dan 6 item unfavourable, state anxiety yang terdiri dari 6 item favourable dan 6 item unfavourable dan Self-confidence yang terdiri 6 item favourable dan 6 item unfavourable.

Proses validasi alat ukur menggunakan metode try out terpakai, sehingga skala disebar satu kali dan digunakan untuk validasi instrumen. Selanjutnya skor pada item yang tidak valid tidak diikutkan dalam perhitungan korelasi antar variabel. Detil penyebaran skala ditulis pada bagian prosedur penelitian. Validitas item dilihat berdasarkan nilai korelasi skor item dengan skor total yang menunjukan untuk skala Kecemasan Kompetitif gugur II item dari 36 item, Adapun detil nilai Validitas dapat dilihat pada tabel 2.

\section{Tabel 2}

Indeks Validitas Alat Ukur Penelitian

\begin{tabular}{lccc}
\hline \multicolumn{1}{c}{ Alat Ukur } & Jumlah Item Diujikan & Jumlah Item Valid & Indeks Validitas \\
\hline $\begin{array}{l}\text { Skala Kecemasan } \\
\text { Kompetitif }\end{array}$ & 36 & 25 & $0,420-0,736$ \\
\hline
\end{tabular}

Berdasarkan Tabel I diperoleh hasil dari 29 item skala iklim organisasi yang diujikan, ada 20 item yang valid setelah diujikan melalui uji statistik mengunakan program SPSS, Indeks validitas dari skala Kecemasan Kompetitif yang diujikan berkisar antara 0,420-0,736

\section{Tabel 3}

Indeks Reliabilitas Alat Ukur Penelitian

\begin{tabular}{cc} 
Alat Ukur & Alpha \\
\hline Skala Kecemasan Kompetitif & 0,938 \\
\hline
\end{tabular}

Berdasarkan tabel 3 dapat disimpulkan bahwa instrument yang dipakai dalam penelitian ini reliabel jika dibandingkan dengan syarat cronbach alpha yaitu 0,60 atau 60\% (priyanto, 20l I). Hal ini membuktikan bahwa kedua instrumen yang digunakan dalam penelitian ini memiliki tingkat validitas dan reliabilitas yang cukup memadai.

Alat ukur ini awalnya berisi 36 item pernyataan yang mengukur tiga dimensi dari variabel kecemasan kompetitif. Setelah melalui tahap field testing/try out dan diuji validitas dan reliabilitas kuesioner kecemasan kompetitif ini ada II item gugur yang tifak memenuhi kualifikasi dalam uji validitas dan reliabilitas sehingga menjadi 25 item. Skala kecemasan ini terdiri dari 25 item yang dibagi menjadi 3 subskala terdiri dari: Cognitive state anxiety yang terdiri dari 8 item (item nomor I, $2,5,7$, item favourable dan item nomor $3,4,6,8$ unfavourable), Somatic state anxiety yang terdiri dari 9 (item nomor 9, 10, 13, 14, 17 item favourable dan item nomor 11,12, I5, 16 unfavourable) dan Self-confidence yang terdiri dari 8 item (item nomor 18, 19, 21, 22, 25 item favourable dan item nomor 20, 23, 24 unfavourable).

Partisipan diminta untuk menentukan intensitas kecemasan yang mereka alami sebelum kompetisi berlangsung dengan menggunakan rentang skala lima point scale. Untuk item favourable nilai I diberikan untuk pilihan jawaban I, yaitu 'paling tidak sesuai dengan diri anda' sedangkan skor 5 diberikan untuk pilihan jawaban 5, yaitu 'sangat sesuai dengan diri anda'. Pada item Unfavourable penilaian dilakukan secara terbalik yaitu skala I dengan nilai 5, skala 2 dengan nilai 4, skala 3 dengan nilai 3 , dan skala 4 dengan nilai 2 dan skala 5 dengan nilai $\mathrm{I}$.

\section{Tabel 4}

\section{Contoh Skala Kecemasan Kompetitif}

\begin{tabular}{llllll}
\hline No & PERNYATAAN & $\mathbf{2}$ & $\mathbf{3}$ & $\mathbf{4}$ & $\mathbf{5}$ \\
\cline { 2 - 5 } 2 & Saya kurang yakin akan kompetisi yang akan saya ikuti & & & & \\
\hline
\end{tabular}


Nilai skor yang diperoleh total dari masing-masing subskala dengan nilai terendah $=0-42$ yang mengindikasikan kecemasan pada kategori yang rendah, nilai sedang $=43-84$ yang mengindikasikan kecemasan pada kategori sedang dan nilai tertinggi $=85-125$ yang mengindikasikan kecemasan pada kategori yang tinggi.

Pelaksanaan Intervensi, Intervensi untuk menurunkan kecemasan kompetitif ini direncanakan akan dilakukan dalam 6 sesi untuk perlakuan intervensi guide imagery dan therapy musik, kemudian 7 sesi untuk intervensi guide imagery and music (GIM), dengan 2 sesi diantaranya hanya digunakan untuk melakukan pre-tes dan post-test.

Intervensi pada kelompok subjek pertama (guide imagery):

Sesi I adalah asesmen pra-intervensi dengan kegiatan santai seperti perkenalan dengan partisipan dan penjelasan mengenai jalannya intervensi guide imagery. Sesi 2 , kegiatan yang dilakukan pada sesi ini adalah melakukan pratest dengan mengisi kuesioner skala kecemasan kompetitif satu/ dua jam sebelum pertandingan dimulai. Sesi 3, Competititve anxiety, kegiatan yang dilakukan terapis mengajak partisipan untuk menemukan dan mengenali kecemasan yang mereka miliki dan melakukan relaksasi pernafasan. Selanjutnya sesi 4, yaitu pengenalan Imagery dan latihan dasar Imagery dimana selanjutnya partisipan dibimbing imagery dengan dibantu oleh terapis dalam membacakan narasi yang ada. Ketika terapis membacakan narasi, partisipan diminta untuk duduk yang nyaman, menutup kedua matanya, dan membayangkan situasi dalam narasi. Selanjutnya terapis mengajak partisipan untuk melatih kemampuan imagery yang mereka miliki dengan membacakan narasi yang masing-masing digunakan untuk meningkatkan kejelasan gambar (vividness), kemampuan mengontrol gambar (controlability), dan kesadaran diri akan pikiran dan perasaan yang ia miliki (selfawareness). Selama latihan imagery berlangsung, partisipan diminta untuk duduk yang nyaman dan menutup kedua matanya. Selanjutnya di sesi 5 yaitu pasca test Skala Kecemasan Kompetitif dengan mengisi kuesioner Skala Kecemasan Kompetitif satu jam sebelum pertandingan dimulai. Selanjutnya pertemuan terakhir pada sesi 6 yaitu asesmen pasca-intervensi, Partisipan diminta untuk menceritakan pengalamannya terkait dengan efektivitas, hambatan, dan perubahan yang dirasa setelah mengikuti program intervensi guide imagery. Partisipan juga diminta untuk mengungkapkan perasaan dan pendapatnya mengenai program intervensi yang telah diberikan. Sehingga, peneliti dapat melihat kontribusi masing-masing sesi dalam membantu partisipan mengatasi kecemasannya. Intervensi pada kelompok subjek kedua (Music Therapy):

Sesi I adalah Asesmen pra-intervensi dengan kegiatan santai seperti perkenalan dengan partisipan dan penjelasan mengenai jalannya intervensi guide music therapy. Sesi 2, kegiatan yang dilakukan pada sesi ini adalah melakukan pre-test dengan mengisi kuesioner skala kecemasan kompetitif satu/dua jam sebelum pertandingan dimulai. Selanjutnya sesi 3, yaitu pengenalan competititve anxiety dan relaksasi musik dimana terapis memberikan informasi mengenai relaksasi music untuk mengurangi ketegangan yang menjadi dampak dari kecemasan. Setelah pemberian informasi mengenai relaksasi music, terapis memandu partisipan untuk berlatih relaksasi music dengan mendengarkan rekaman yang telah disediakan. Selanjutnya di sesi 4, yaitu Pengenalan terapi musik dan latihan terapi musik, terapis memberikan informasi mengenai terapi musik. Setelah itu partisipan di minta untuk memejamkan mata sambil mendengar alunan musik untuk mengurangi kecemasan kompetitifnya. Selanjutnya di sesi 5 yaitu pos-test Skala Kecemasan Kompetitif dengan mengisi kuesioner Skala Kecemasan Kompetitif satu jam sebelum pertandingan dimulai. Selanjutnya pertemuan terakhir pada sesi 6 yaitu asesmen pasca-intervensi, Partisipan diminta untuk menceritakan pengalamannya terkait dengan efektivitas, hambatan, dan perubahan yang dirasa setelah mengikuti program intervensi music therapy. Partisipan juga diminta untuk mengungkapkan perasaan dan pendapatnya mengenai program intervensi yang telah diberikan. Dengan demikian peneliti dapat melihat kontribusi masing-masing sesi dalam membantu partisipan mengatasi kecemasannya. 
Intervensi pada kelompok subjek ketiga (Guide imagery and music):

Pada intervensi guide imagery and music Sesi I adalah Asesmen pra-intervensi dengan kegiatan santai seperti perkenalan dengan partisipan dan penjelasan mengenai jalannya intervensi GIM. Kemudian pada pertemuan berikutnya yaitu sesi 2, kegiatan yang dilakukan pada sesi ini adalah melakukan pretest dengan mengisi kuesioner Skala Kecemasan Kompetitif satu/dua jam sebelum pertandingan dimulai. Berikutnya yaitu sesi 3 , kegiatan yang dilakukan adalah competititve anxiety dan relaksasi musik setelah pertandingan, dimana pada sesi ini peneliti memberikan informasi mengenai kecemasan dan kecemasan kompetitif. Setelah peserta mengemukakan dampak yang mereka rasakan ketika kecemasan muncul, peneliti memberikan informasi mengenai relaksasi music dan peneliti memandu partisipan untuk berlatih relaksasi musik dengan mendengarkan rekaman yang telah disediakan. Selanjutnya sesi 4, yaitu pengenalan Imagery dan latihan dasar Imagery dimana kegiatan yang dilakukan dalam sesi ini yaitu peneliti memberikan informasi mengenai imagery dan dan peneliti memandu partisipan untuk berlatih imagery.

Selanjutnya di sesi 5 yaitu penerapan Imagery and music (GIM) peneliti mengintegrasikan kecemasan dan pernyataan kognitif partisipan terkait dengan pertandingan yang akan berlangsung ke dalam narasi yang telah dibuat pada pertemuan sebelumnya. Selanjutnya peneliti membacakan narasi tersebut dan meminta partisipan untuk menutup mata dan membayangkannya dengan alunan musik sebelumnya. Selanjutnya di sesi 6 yaitu post-test Skala Kecemasan Kompetitif dengan mengisi kuesioner Skala Kecemasan Kompetitif satu jam sebelum pertandingan dimulai. Selanjutnya pertemuan terakhir pada sesi 7 yaitu asesmen pasca-intervensi, Partisipan diminta untuk menceritakan pengalamannya terkait dengan efektivitas, hambatan, dan perubahan yang dirasa setelah mengikuti program intervensi imagery and music (GIM).

Peneliti juga meminta feedback kepada partisipan mengenai program intervensi imagery and music (GIM) yang telah mereka ikuti.dan yang terakhir adalah tahap evaluasi, tahap evaluasi dilakukan dalam penelitian ini bertujuan untuk melihat adanya atau tidaknya perubahan tingkat kecemasan kompetitif setelah partisipan mengikuti intervensi imagery and music (GIM). Perubahan tersebut diketahui melalui skor alat ukur CSAI-2 yang diisi oleh partisipan sebelum mengikuti pertandingan di kompetisi kedua. Selain itu evaluasi juga dilakukan dimana partisipan diharapkan dapat mengungkapkan adanya perubahan yang terjadi pada kecemasan yang dimiliki setelah mengikuti program intervensi. Partisipan juga diminta untuk mengungkapkan perasaan dan pendapatnya mengenai program intervensi yang telah diberikan. Dengan demikian peneliti dapat melihat kontribusi masing-masing sesi dalam membantu partisipan mengatasi kecemasannya.

Data hasil intervensi akan diukur secara kuantitatif. Peneliti akan membandingkan hasil pengukuran skala kecemasan kompetitif sebelum dan setelah intervensi diberikan kepada partisipan. Alat ukur ini diberikan satu/dua jam sebelum pertandingan dimulai, yaitu setelah sesi pertama diberikan, dan satu jam sebelum pertandingan dimulai, yaitu setelah sesi kelima diberikan. Kriteria efektifitas intervensi secara kuantitatif dilakukan dengan melihat penurunan skor pada alat tes tersebut. Jika skor skala kecemasan pada pertandingan kedua mengalami penurunan dibandingkan dengan skor pada pertandingan pertama, intervensi guide imagery and music ini dapat dikatakan berhasil. Peneliti akan membandingkan mana yang lebiih efektif untuk menurunkan kecemasan atlet sebelum bertanding, apakah intervensi guide imagery, therapy music atau guide imagery and music.

Analisis data yang digunakan dalam penelitian ini adalah Uji Wilcoxon, Kruskal-Wallis dan Mann Whitney yang merupakan uji statistik non parametrik yang dapat digunakan untuk menguji apakah ada perbedaan yang signifikan antara kelompok variabel independen dengan variabel dependennya dan membandingkan kelompk mana yang paling signifikan mengalami perubahan. Karena untuk melihat perbedaan yang signifikan antar kelompok, Uji Kruskal-Wallis biasa digunakan sebagai alternatif untuk uji oneway ANOVA, dimana asumsi kenormalan tidak terpenuhi. Digunakan untuk membuat perbandingan antara dua atau lebih variabel kuantitatif berbentuk ranking dimana sampelnya merupakan sampel independen. 


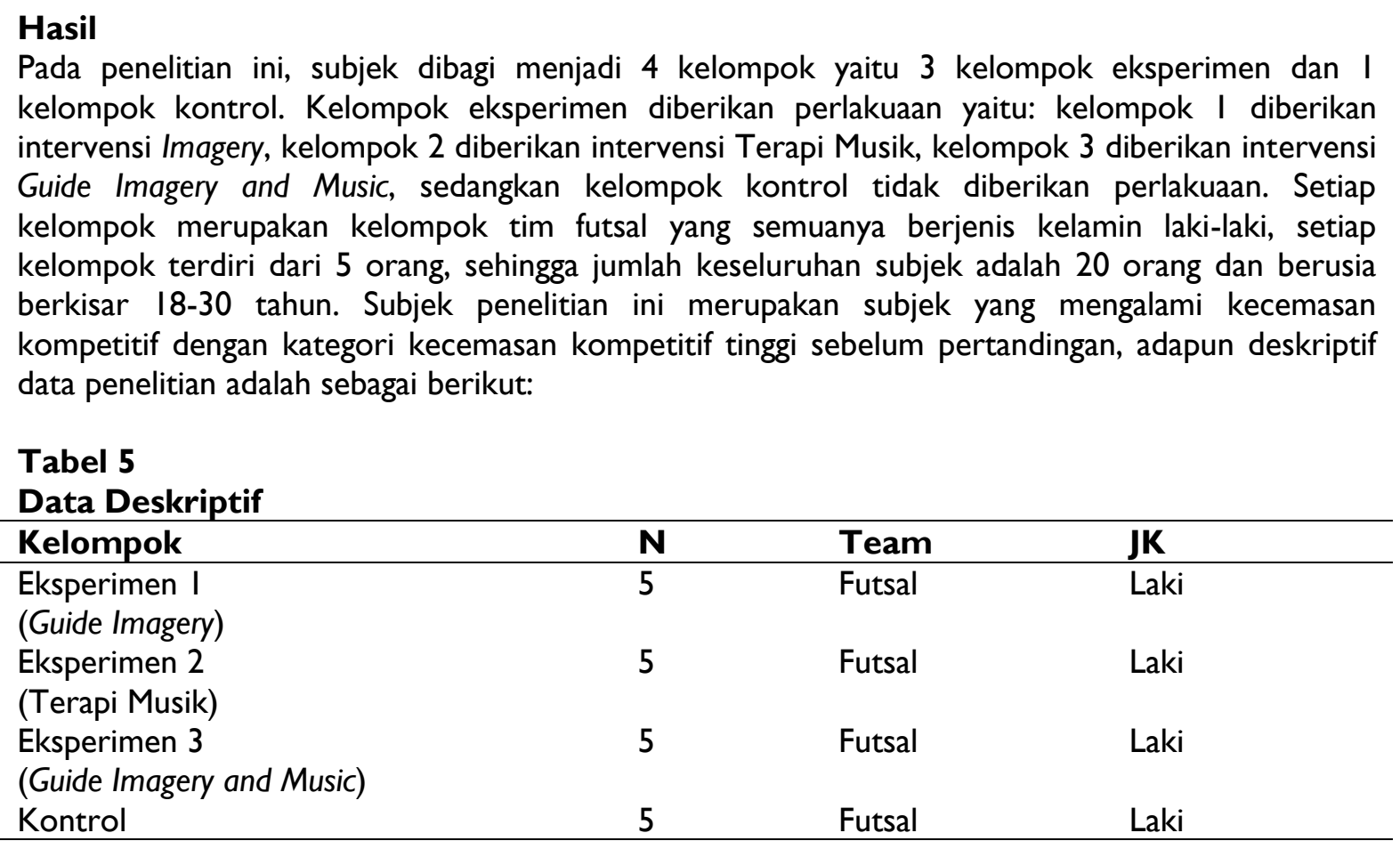

Analisis data yang dilakukan adalah analisis non parametrik. Analisis non parametrik digunakan ketika prosedur statistik data tidak berdistribusi normal seperti data parametrik (Girish, 2018; Neideen \& Brasel, 2007). Analisis non parametrik yang digunakan pada penelitian ini adalah uji uji Wilcoxon, Kruskal-Wallis dan Uji Mann Whitney. Uji Wilcoxon digunakan bertujuan untuk melihat perbedaan hasil pra test dan pasca test pada masing-masing kelompok. Uji kruskal-Wallis bertujuan untuk melihat perbedaan/ perbandingan ke 4 kelompok yaitu 3 kelompok eksperimen dan I kelompok Kontrol. Uji Mann Whitnney bertujuan untuk melihat perbedaan penurunan kecemasan kompetitif mana yang lebih efektif dari kelompok eksperimen I, Kelompok eksperimen 2, kelompok eksperimen 3 dan kelompok kontrol.

\section{Tabel 6}

Hasil perbandingan Pre Test - Post Test

\begin{tabular}{lllll}
\hline Kelompok & $\bar{X}$ Pre-Test & $\bar{X}$ Post-Test & Z & Sig \\
\hline Guide Imagery & 90,4 & 76,6 & $-2,032$ & 0,042 \\
Terapi Musik & 89,2 & 79,8 & $-2,023$ & 0,043 \\
Guide Imagery and Music & 88,6 & 69,4 & $-2,032$ & 0,042 \\
Kontrol & 88,2 & 87,4 & $-1,414$ & 0,157 \\
\hline
\end{tabular}

Berdasarkan tabel 6, hasil perbandingan Pre-test dan Post-test, dilihat dari hasil uji Wilcoxon pada ke empat kelompok subjek diatas menunjukkan terjadinya penurunan kecemasan kompetitif dari masing-masing kelompok yaitu kelompok Guide imagery, Terapi Musik, Guide Imagery and Music dan kelompok kontrol. Dari hasil nilai sig atau p dilihat kelompok I yaitu 0,042, kelompok 2 yaitu 0,043 , kelompok 3 yaitu 0,042 dan kelompok 4 yaitu 0,157. Nilai probabilitas adalah 0,05 yang berarti nilai probalitas kelompok eksperimen $<0.05$ dan nilai probabilitas kelompok kontrol > 0,05 . Maka dapat disimpulkan bahwa adanya perbedaan signifikan hasil pre-test dan post-test masing-masing kelompok eksperimen dan tidak ada perbedaan signifikan hasil dari kelompok kontrol. 


\section{Tabel 7}

\section{Kruskal-Wallis}

\begin{tabular}{ll}
\hline Kelompok & Mean Rank \\
\hline Guide Imagery & 9,2 \\
Terapi Musik & 11,5 \\
Guide Imagery and Music & 3,3 \\
Kontrol & 18 \\
\hline Kruskal-Wallis & Nilai \\
\hline Chi-Square & 15,970 \\
df & 3 \\
Sig & 0,001 \\
\hline
\end{tabular}

Berdasarkan tabel 7 Kruskal-Wallis, Hasil menunjukkan Skor $\mathrm{p}$ uji Kruskal-Wallis ke empat kelompok yaitu 0,00I sedangkan nilai probabilitas adalah 0,05. 0,00I $<0,05$. Maka dapat disimpulkan bahwa ada perubahan signifikan dari keempat kelompok yaitu kelompok, Guide Imagery, Terapi Musik, Guide Imagery and Music dan Kelompok Kontrol.

\section{Tabel 8}

\section{Mann Whitney}

\begin{tabular}{lllll}
\hline Kelompok & $\begin{array}{l}\text { Guide } \\
\text { Imagery }\end{array}$ & Terapi Musik & $\begin{array}{l}\text { Guide Imagery } \\
\text { and Music }\end{array}$ & Kontrol \\
\hline Guide Imagery & & $-1,379$ & $-2,635^{*}$ & $-2,668^{* *}$ \\
Terapi Musik & & $-2,312^{*}$ & $-2,652^{* *}$ \\
$\begin{array}{l}\text { Guide Imagery and Music } \\
\text { Kontrol }\end{array}$ & & & $-2,660^{* *}$ \\
$*=$ Signifikan ** = Sangat Signifikan & & &
\end{tabular}

Berdasarkan Tabel 8 Hasil uji Mann Whitney menunjukkan hasil untuk mengetahui perbedaan masing-masing kelompok yang dilakukan antar variable kelompok. Intervensi kelompok guide imagery dan kelompok terapi musik menunjukkan tidak ada perbedaan siginifikan penurunan kecemasan kompetitif $(Z=-1,379, p=0,222)$. Kelompok Guide imagery dan Guide imagery and Music menunjukan ada perbedaan signifikan penurunan kecemasan kompetitif $(Z=-2,635, p=$ 0,008 ). Kelompok guide imagery dan kelompok Kontrol, menunjukkan adanya perbedaan yang signifikan antara intervensi guide imagery dengan kelompok kontrol $(Z=2,668, p=0,008)$.

Kelompok Terapi Musik dan kelompok Guide Imagery and Music, menunjukkan adanya perbedaan yang signifikan antara intervensi guide imagery dengan kelompok control $(Z=-2,312, p=0,016)$. Kelompok Terapi Musik dan kelompok Kontrol, menunjukkan adanya perbedaan yang signifikan antara intervensi guide imagery dengan kelompok control $(Z=2,652, p=0,008)$ Kelompok guide imagery and Music dan kelompok Kontrol, menunjukkan adanya perbedaan yang signifikan antara intervensi guide imagery dengan kelompok control $(Z=2,660, P=0,008)$.

\section{Pembahasan}

Hasil penelitian menunjukkan adanya pengaruh dari intervensi Guide imagery, Terapi Musik, Guide Imagery and Music, maupun kelompok kontrol. Pada setiap kelompok mengalami penurunan kecemasan kompetitif, dimana kelompok Guide imagery and music yang paling signifikan mengalami penurunan kecemasan kompetitif.

Dalam konteks olahraga, kecemasan atau emosi negatif biasa muncul sebagai respon dari tekanan kompetitif, yang biasa disebut dengan kecemasan kompetitif (competitive anxiety) (Mellalieu, Hanton, \& Fletcher, 2009). Salah satu faktor individu yang ditemukan paling konsisten mempengaruhi performa atlet adalah competitive state anxiety (kecemasan kompetitif). Hasil penelitian membuktikan bahwa kecemasan berpengaruh besar terhadap kemungkinan penampilan atlet, yang dengan sendirinya akan berpengaruh terhadap prestasinya (Setyobroto, 2002). 
Pada kelompok yang diberi perlakuan Guide Imagery terdapat penurunan kecemasan kompetitif dilihat dari hasil rata-rata Pre-Test sebesar 90,4 menjadi sebesar 76,6 dengan nilai sig 0,042. guide Imagery menggunakan seluruh indra untuk menciptakan atau menciptakan kembali sebuah pengalaman di dalam pikiran (Vealey \& Greenleaf, 200I). Terdapa tiga kunci utama untuk memahami imagery, yaitu menciptakan atau menciptakan kembali pengalaman dalam pikiran. Imagery didasari oleh memori,dan individu mengalami memori tersebut secara internal dengan melakukan rekonstruksi terhadap pengalaman eksternal didalam pikiran. Selain itu, imagery juga dapat digunakan untuk menciptakan pengalaman baru dalam pikiran. Dalam penelitian ini subjek diberikan pengalaman dalam pikiran yaitu peneliti mencoba membawa subjek untuk membayangkan pertandingaan yang akan di hadapi dengan menampilkan penampilan terbaik. Jika di lihat lebih lanjut, hasil dari penelitian ini dari kelima subjek pada kelompok ini hanya 3 subjek yang mengalami penurunan dari kategori kecemasan tinggi menjadi kecemasan dengan kategori kecemasan sedang, dan dua subjek lainnya tetap dengan kategori kecemasan tinggi.

Pada kelompok yang diberi perlakuan Terapi musik terdapat penurunan kecemasan kompetitif dilihat dari hasil rata - rata Pre-Test sebesar 89,2 menjadi sebesar 79,8 dengan nilai sig 0,043. Musik dapat meningkatkan endorfin dan mempengaruhi suasana hati serta bisa menurunkan kecemasan melalui gelombang suara (Merrit, 2003). Pada kelompok ini peneliti mencoba membuat situasi rileks terhadap subjek dengan mendengarkan musik instrumental. Yuanita (2008) dalam penelitian menyebutkan bahwa pemberian terapi musik bisa memberikan stimulasi otak memaluli nada-nada yang didengarkan dan bisa menurunkan kecemasan. Jika di lihat lebih lanjut, hasil dari penelitian ini dari kelima subjek pada kelompok ini hanya 3 subjek yang mengalami penurunan dari kategori kecemasan tinggi menjadi kecemasan dengan kategori kecemasan sedang, dan dua subjek lainnya tetap dengan kategori kecemasan tinggi.

Pada kelompok yang diberi perlakuan Guide Imagery and music terdapat penurunan kecemasan kompetitif dilihat dari hasil Pre-Test sebesar 88,6 menjadi sebesar 69,4 dengan nilai sig 0,042. Domenech dan Montserrat (2008) menyebutkan ada empat fase didalam Guide Imagery and Music. Fase pertama adalah prelude, pada fase ini individu mengungkapkan keluhan yang sedang dirasakan. Fase kedua adalah induction pada fase ini terapis akan memberikan sugesti verbal untuk merilekskan tubuh individu dan mempersiapkan individu untuk mendengarkan musik beserta bimbingan imageri. Fase ketiga adalah Music-Imagery Experience, pada fase ini subjek akan di beri bimbingan imageri dan diperdengarkan music. Fase keempat adalah postlude, pada tahap inin adalah fase untuk mengakhiri proses guide imagery and music. Dalam kelompok ini keseluruhan subjek mengalami penurunan kategori kecemasan kompetitif dari tinggi menjadi sedang. Antusias subjek dan kondusifnya keadaan intervensi membuat intervensi ini berjalan dengan lancar.

Pada kelompok kontrol terdapat penurunan kecemasan kompetitif dilihat dari hasil Pre-Test sebesar 88,2 menjadi sebesar 87,4 dengan nilai sig 0,157. Walaupun keseluruhan subjek tidak mengalami perubahan kategori kecemasan kompetitif. Tetapi ada perubahan skor dari rata-rata Pre-test dan Post-test pada kelompok kontrol.

Kecemasan kompetitif merupakan hasil dari kecemasan dasar atlet dalam mempersepsikan situasi kompetisi (Spielberger, 1966). Menurut Jarvis (1999), kecemasan yang kita rasakan pada satu saat tertentu merupakan hasil pembentukan psikologis individu dan karakteristik dari situasi dimana individu berada. Oleh sebab itu, faktor individual dan situasional perlu diperhitungkan ketika menghadapi suatu pertandingan. Hasil peneltian membuktikan bahwa kecemasan berpengaruh besar terhadap kemungkinan penampilan atlet, yang dengan sendirinya akan berpengaruh terhadap prestasinya (Setyobroto, 2002).

Secara keseluruhan, proses intervensi dapat dikatakan berjalan cukup lancar karena setiap sesi dapat dilakukan sesuai modul yang ada sebelum pertandingan dilakukan. Peneliti juga tidak mengalami kesulitan mendapatkan ruang yang nyaman dan tenang agar partisipan dapat menerima materi dengan baik. 
Berdasarkan penjelasan diatas, dari keempat kelompok didapatkan hasil kelompok 3 yaitu kelompok guide imagery and music adalah kelompok yang paling mengalami perubuhan signifikan, yaitu menurunnya kecemasan kompetitif pada tiap subjek. Kelompok ini merupakan kelompok kombinasi dimana ada unsur imagery yaitu menciptakan atau menciptakan kembali pengalaman dalam pikiran dan unsur musik yang membuat stimulasi menyenangkan dengan pelepasan zat endorphin dalam otak. Dengan proses pada intervensi pada guide imagery and music, situasi kondusif dan didukung oleh antusias subjek menyebabkan intervensi ini lebih efektif dari intervensi guide imagery atau terapi musik.

\section{Kesimpulan}

Hasil penelitian menunjukkan bahwa pemberian intervensi kombinasi Guide Imagery and Music lebih efektif dibanding intervensi Guide Imagery dan Terapi musik. Hasil ini terlihat dari penurunan skor kecemasan kompetitif pada kelompok eksperimen saat pre-test dan post-test. Selain itu, adanya perbedaan signifikan kecemasan kompetitif saat dilakukan uji beda dengan Uji Mann Whitnney antara kelompok eksperimen dan kelompok kontrol. Penelitian ini memiliki kekurangan dan keterbatasan yaitu pengukuran kecemasan dengan menggunakan alat ukur lain yang dapat menjadi bahan pertimbangan efektivitas dari intervensi, Waktu pengukuran kecemasan disesuaikan agar hasilnya dapat maksimal dan tidak terganggu oleh kondisi pertandingan itu sendiri, Melakukan kontrol terhadap faktor-faktor lain dianggap memberikan pengaruh terhadap hasil intervensi, Menggunakan sampel yang lebih banyak agar dapat melakukan uji signifikansi terhadap perubahan yang terjadi pada partisipan.

\section{REFERENSI}

Aizid, R. (20I I). Sehat dan cerdas dengan terapi music. Yogyakarta: Laksana.

Allison. (200I). Pengantar psikologi. Batam: Interaksara.

Atkinson R. L., Atkinson, R. C., Hilgard E. R. (1994). Pengantar psikologi edisi kedelapan. Jakarta: Erlangga.

Bee, L. H., \& Wyatt T., H. (2009). Guided imagery \& music using the bonny method to evoke emotion \& access the unconscious. Journal of Psychosocial Nursing, 47 (I), 29-33.

Besharat, M. A., \& Pourbohlool, S. (20II). Moderating effects of self-confidence and sport selfefficacy on the relationship between competitive anxiety and sport performance. Journal of Sport Psychology, 2, 760-765.

Bita, E., Somayeh, Mahdi, O. M., Seyedeh, S. M., Seyedeh, M. H., Zahra T., Mehdi S. (20I3). The relationship between competitive anxiety and performance level of female students of yazd medicine. International Journal of Sport Studies, 3, (7).

Bonny. Helen L., \& Savary, Louis M. (1986). Music and your mind, listening with a new consciousness. New York: Station Hill Press.

Callow, N., Hardy, L., \& Hall, C. (200I). The effect of motivational general mastery intervention on the sport confidence of high-level badminton player. American Alliance for Health, Physical Education, Recreation and Dance, 72, 389-400.

Chaplin, J. P. (2002). Kamus lengkap psikologi. Jakarta: Raja Grafindo Persada.

Cox, R. H., Martens, M. P., \& Russell, W. D. (2003). Measuring anxiety in athletics: the revised competitive state anxiety inventory. Journal of Sport \& Exercise Psychology, 25, 519-533.

Cox, R. H. (2003). Sport Psychology: Concepts and applications sixth edition. Mc-Graw-Hill International Edition. 
Davies, K. dan Newstrom, J. (1989). Human behavior at work. Singapore: Mc. Graw-Hill. International.

Djohan. (2006). Psikologi musik. Yogyakarta: Buku Baik.

Domenech, I. G., \& Montserrat (2008), The effect of music and imagery to induce relaxation and reduce nausea and emesis in cancer patients undergoing chemotherapy treatment, UMI Dissertations Publishing, 119.

Dunn, K. (2004). Music and the reduction of post-operative pain. Nursing Standard. 18 (36), 33-39.

Esfahani, N., \& Soflu, H. G. (20II). Relationship between emotional intelligence and transformational leadership in physical education managers. Social and Behavioral Sciences, 30, 2384-2393.

Eys, M. A., Hardy, J., Carron, A. V., Beauchamp, M. R. (2003). The relationship between task cohesion and competitive state anxiety. Journal of Sport \& Exercise Psychology, 66-76.

Firmansyah, H. (20II). Perbedaan pelatihan imagery dan latihan tanpa imagery Terhadap Keterampilan Senam dan Kepercayaan Diri Atlet. Jurnal Olahraga Prestasi, I- I0.

Good, T. L., dan Brophy, J. E. (1990). Educational psychology. New York: Longman.

Hale, B. D., \& Whitehouse, A. (1998). The effects of imagery manipulated appraisal on intensity and direction of competitive anxiety. The Sport Psychologist, 12, 40-5I.

Hidayat, Y. (20I I). The Effect of goal setting and mental imagery intervention on badminton learning achievement motor skill at 10-12 yearso: the context of indonesia. International Journal for Educational Studies, I29-I44.

Jarvis. (1998). The theory and practice of Learning, London: Kogan Page Limited.

Jones, G., Swain, A. (1996). Explaining performance variance: The relative contribution of intensity and direction dimensions of competitive state anxiety. Anxiety, Stress, and Coping, 9, I-I8.

Kozier, B., Erb, G., Berman, A., \& Snyder, S. (2010). Fundamentals of nursing, concepts, process, and practice. California: Addison Wesley.

Kumar. (1999). Research Methodology: A step by step guide for beginners. London: Sage Publications.

Kwekkeboom, K. L., Cherwin, C. H., Lee, J.W., \& Wanta, B. (2010), Mind body treatments for the pain fatigue sleep disturbance symptom cluster in persons with cancer, Journal of Pain and Symptom Management, 39.

Levy, A. R., Nicholls, A. R., Polman, R. C. J. (2009). Pre competitive confidence, coping, and subjective performance in sport: Scand J Med Sci Sports.

Lowther, J., Lane, A. (2002). Relationship between mood, cohesion, and satisfaction with performance among soccer players. athletic insight: The Online Journal of Sport Psychology, 4.

Martens, R., Vealey, R. S., \& Burton, D. (1990). Competitive anxiety in sport. Champaign. Human Kinetics.

Martin, K. A., \& Hall, C. R., (1995). Using mental imagery to enhance intrinsic motivation. Journal of Sport \& Exercise Psychology, I7, 54-69.

Mellalieu, S. D., Hanton, S., \& Fletcher, D. (2009). A competitive anxiety review: recent direction in sport psychology research. New York: Nova Science Publishers.

Merrit, S. (2003). Simfoni otak. Bandung: Kaifa.

Michele A. Bertini (200I). The effects of guided imagery and music on anxiety. A Dissertation Submitted to the Faculty of Holos University.

Natalina Dian. (2013). Terapi musik bidang keperawatan. Jakarta: Mitra Wacana Media. 
Nilsson, U. (2009). Caring Music: Music Intervention for Improved Health. (Online). (www.orebroll.se/uso/page_2436.aspx, diakses tanggal 2 September 2018).

Pasero, C., \& McCaffery, M. (2007). Orthopaedic post-operative pain management. Journal of Peri Anesthesia Nursing, 22 (3).

Prasetyo, Bambang, Lina M.J, (2008). Metode penelitian kuantitatif: teori dan aplikasi, Jakarta: PT Raja Grafindo Persada

Raley, S (2006), The experience of healing in the bonny method of guided imagery and music, Proquest, $I$.

Ramzaninezhad, R., Keshtan, M. H., Shahamat, M. D., \& Kordshooli, S. S. (2009). The relationship between collective efficacy, group cohesion and team performance in professional volleyball teams. Brazilian Journal of Biomotricity, 31-39

Satiadarma, M. P. (2000). Dasar-dasar psikologi olahraga. Jakarta: Pustaka Sinar Harapan.

Setyobroto, S. (2002). Psikologi olah raga. Jakarta: Universitas Negeri Jakarta.

Short, AE. (2003). Holistic aspects of rehabilitation post-cardiac surgery in the bonny method of guided imagery and music, UTS Press Publishing, 42-266.

Singh, A., \& Gaurav, V. (20II). A study of pre-competitive and post-competitive anxiety level of inter collegiate volleyball players. International Journal of Sports Science and Engineering, 5 (04), 237-24I.

Smith, R. E., Smoll, F. L., Cumming, S. P., \& Grossbard, J. R. (2006). Measurement of multidimensional sport performance anxiety in children and adults: the sport anxiety. Journal of Sport and Exercise Psychology, 28 (4), 479-50I.

Subandi, M.A. (2002). Psikoterapi: pendekatan konvensional dan kotemporer. Yogyakarta: Unit Fakultas Psikologi UGM.

Sudjana. (1996) Metode statistika, Bandung: Penerbit Tarsito.

Sugiyono. (2015). Metode penelitian kuantitatif kualitatif $r \& b$. Bandung: Aflabeta.

Suhartini. (2008). Prosedur penelitian suatu pendekatan praktek, edisi revisi V. Jakarta: Rieka Cipta.

Spielberger, Charles D. (1966). Anxiety and behavior. New York: Academik Press

Vealey, R. (200I). Understanding and enhancing self confidence in athletes. New York: Wiley.

Vincent Parnabas. (2015). The effect of competitive state anxiety on sport performance among sepak takraw. International Journal of Sport Studies 2.

Wigram, A., L. (2002). The effects of vibroacoustic therapy on clinical and non-clinical population. st. georges hospital medical schooll london university. Published Dissertation Paper.

Woodman, T., \& Hardy, L. (2003). The relative impact of cognitive anxiety and self-confidence upon sport performance: a meta-analysis. Journal of Sport Sciences, 21 , 443-457

Yuanitasari Lena. (2008). Terapi musik untuk anak balita, panduan untuk mengoptimalkan kecerdasan anak melalui musik. Yogyakarta: Cemerlang Publishing. 